\author{
DEPARTMENT OF THE INTERIOR \\ UNITED STATES GEOLOGICAL SURVEY
}

PREPARED IN COOPERATION WITH THE

COMMONWEALTH OF MASSACHUSETTS

DEPARTMENT OF PUBLIC WORKS

\title{
AEROMAGNETIC MAP OF THE NATICK QUADRANGLE MIDDLESEX AND NORFOLK COUNTIES, MASSACHUSETTS
}

GEOPHYSICAL INVESTIGATIONS

MAP GP-675

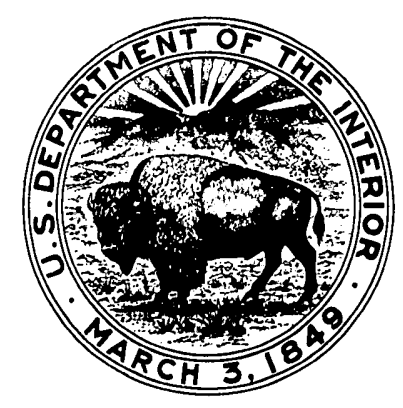

